bowel itself showed no sign of tuberculons ulceration, the only observable lesion being the adhesive peritonitis before mentioned. The brain on examination proved to be quite normal, except that the convolutions were poorly developed; there was no sign of any cerebral abscess.

The interesting features of this case were the remarkable pancity of symptoms pointing to the precise nature of the pathological condition and the unusual ultimate ending of the case. The fact of the boy being an imbecile precluded the possibility of obtaining any subjective symptoms and materially added to the difficulty of diagnosis.

I am publishing the notes of this case by kind permission of Dr. H. O. Brown, under whose care the patient was placed.

Dudley.

\section{NOTE ON A CASE OF ACUTE PULMONARY CEDEMA.}

By Oharles E. Denning, L.R.C.P. \& S. Irel., L.M.

THE following report of a case which came under my care will no doubt be of interest to readers of THE LANCET.

A married woman, aged 39 years, who had been under medical treatment for " heart disease and occasional cough," was advised in view of her approaching confinement in July to go to the country for a change. On April 5th she came to a farmhouse in this neighbourhood and her health improved somewhat. But she still suffered from "shortness of breath." On April 26th she was in her usual health and walked in the afternoon and after supper went to bed. Almost at once she began to cough and at 1.30 A.M. I was called up to see her, the message being, "a woman has been coughing for three hours without ceasing and cannot stop." I saw her within half al hour and found her sitting up in bed in very great distress, breathing 48 times a minute, about every third gasp being a barking cough. It was not at all like the rapid breathing of acute pneumonia or pleural effusion, but the woman was struggling for breath and in fear of suffocation. Her friends had tried to give her brandy, but she said that she had not time to swallow anything. Up to this time, three and a half hours from the commencement of the attack, there had been no expectoration.

On examination I found moist râles all over the lungs back and front, but owing to the noisy breathing and cough I could not distinguish the heart sounds. The pulse was 120 . I had just finished my examination when the patient coughed up two mouthfuls of rose-pink froth and continued doing so at short intervals up to the time of her death at 6 A.M. Sometimes the froth gushed out of the mouth and nostrils and at others she coughed it up with a little pinktinted serum, the total quantity collected in a basin amounting to four ounces. This fluid on settling was of a red colour covered with foam, exactly like beer froth. I was much exercised in $\mathrm{mr}$ mind how to account for this sudden and alarming illness until I saw the rose-tinted froth issuing from the mouth, when it at once occurred to me that here was a case of acute pulmonary codema such as those recently reported in THE LANCE'r, Dr. Leonard Williams first writing on the subject on Dec. 7th, 1907.' I injected strychnine and atropine, and later strychnine and digitalin, without appreciable advantage; and I also introduced an exploring needle into the pleura to make quite certain there was no pleural effusion and found there was none. The patient complained of suffocation and became gradually more cyanosed and died at 6 A.M.-i.e., eight and a half hours from the commencement of the attack.

I was only allowed to make a partial necropsy and did so nine hours after death. There were several pleural adhesions but no trace of tubercle. There was about one pint of bloodstained serum in the pleural cavities. Both lungs were absolutely waterlogged - in fact, they presented the appearance of a person who had died from drowning. On section, reddish serum and froth flowed away in large quantities. The heart presented no abnormal features excepting that the mitral valves were much thickened, one valve especially had a distinct patch of atheroma, and there was marked incompetence.

Epping, Essex.

1 Leonard Williams : Acute Pulmonary Edema, THE LaxceT, Dec. 7th, 1907, p. 1606.
A CASE OF HAMOPHILIA IN THE NEWLY BORN.

By F. G. M. BrIT'TIN, M.R.C.S., L.S.A.

Mrs. —-, aged 37 years, is a large-framed and very anæmic woman. She has had five confinements, each requiring forceps and chloroform, and in each severe postpartum hæmorrhage has occurred. On April 16th I was called to see her and found that she had been in labour several hours. The os was fully dilated, the head was presenting, the membranes were unruptured, and there was no caput succedaneum. I found the lumbo-sacral promontory very prominent and evidently obstructing labour. Under chloroform I turned and brought down the child's right foot and delivered the child in five minutes without the slightest trouble. There was no undue traction necessary. On the 17th I was asked to cut the child's frænum linguæ. It was very short, so I peeled it back with my finger to satisfy the mother. On the 18th I visited the case and found that persistent oozing from the frænum had occurred since $I$ peeled it back. The whole of the frontal region was black, distended, and fluctuating. This swelling extended backwards over the skull and downwards behind the ears, which were pushed out. The skin as far as the clavicles was black. The right shoulder and arm were darkly ecchymosed and the right foot and leg were also darkly coloured. On the 19th the eyelids were black and the breathing was stertorous. The child died at 5 P.M.

In 43 years' general practice I have never seen a similar case and can only conclude that the extraordinary subcutaneous hæmorrhage was due to some hæmophilic tendency in the infant.

Papanui, New Zealand.

\section{A CASE OF ASCTTES IN THE NEWLY BORN.}

BY H. M. INGLIS, M.B., C.M. EDrN., HOXORARY PHISICIAN, CHRISTCHURCH HOSPITAL.

I ATTENDED Mrs. - - in her second confinement recently Labour was normal, but there was a slight difficuity in delivering the body of the child. I found the child's abdomen very much distended, being so tense that I could not palpate any of the abdominal organs. About 12 hours after birth the child passed a large quantity of urine, the abdominal tension becoming much less pronounced, the wails being slack enough to allow me to feel the organs. The heart sounds were normal. Death occurred 36 hour after birth. On post-mortem examination I found a considerable quantity of bile-stained fluid in the peritoneal cavity. The omentum was so thin that I could not define it accurately. The intestines appeared to be covered with blisters, the largest being of the size of a walnut. As far as I could judge these blisters were little sacs of fluid on the under surface of a thinned-out omentum. All the organs were apparently normal. I attended this child's mother in her first confinement when the child died shortly after birth with a considerably enlarged liver.

Christchurch, New Zealand.

1 We are indebted to Dr. P. Clennell Fenwick, of Christchurch, New Zealand, for communicating two interesting cases reported by medical men in New Zealand.-ED. L.

Triennial Dinner of the Epsomian Club.The triennial dinner of the Epsomian Club was held at Epsom on July 7th when the nembers were entertained by the Council of the College and the headmaster. 35 member dined. Speeches were made by the Rev. T. M. H. Smith Pearse, Dr. G. R. F. Stilwell of Beckenham, Mr. L. L. C. Reynolds, and $\mathrm{Mr}$. A. J. Newrom who was presented with a small token of the esteem in which he was held during the many years in which he had commanded the Rifle Corps. Amongst the old Epsomians present were Mr. Clement Smiles, Mr. G. S. Boulger, Mr. Sydney Stephenson, Dr. H. Campbell Thomson, Mr. Edred M. Corner, and Captain T. G. Mair. It was a beautiful afternoon and the College was playing the Surrey Club and Ground at cricket. Those present were much impressed with the immense amount that was being done for the benefit of the buildings and the boys, and the general progress since the majority of the club had left. 